\title{
Europe (2019)
}

\author{
Federico Casolari*
}

\section{Developments within the Council of Europe}

Global warming is a concern shared by all nations. It is estimated that 200 million people will be displaced globally by 2050 because of climate change. ${ }^{1}$ It is not surprising then that environmentally induced migration has become a topical issue at a policy level. This said, a clear legal framework recognising the rights of displaced people is still lacking at an international level, and, with the exception of the Kampala Convention for the protection and assistance of internally displaced persons in Africa, ${ }^{2}$ all major initiatives have led so far to the elaboration of non-binding instruments. ${ }^{3}$

In the wake of this trend, in October 2019, the Parliamentary Assembly of the Council of Europe (PACE) has adopted a non-binding resolution on 'A legal status for "climate refugees".'4 Following its Resolution 1655 (2009) and Recommendation 1862 (2009) 'Environmentally induced migration and displacement: a 21st-century challenge', the PACE has called the Member States of the Organization to adopt a more proactive approach to the protection of the victims of natural and man-made disasters, improving disasters preparedness

* Associate Professor of EU Law, Alma Mater Studiorum - University of Bologna. This survey is realized within the framework of the Research Project of National Relevance 'International legal obligations related to Prevention, Preparedness, Response and Recovery from CBRN events and status of their implementation in Italy-CBRN in Italy', funded by the Italian Ministry of the University (ref. 20175M8L32).

1 Norman Myers, 'Environmental refugees: A growing phenomenon of 21st century', (2002) 357 Philosophical Transactions of the Royal Society London B, 6o9, available at <https://www .ncbi.nlm.nih.gov/pmc/articles/PMC1692964/pdf/12028796.pdf> last accessed (as any subse quent URL) on 6 July 2020.

2 The Kampala Convention has been adopted under auspices of the African Union in 2009 and entered into force in 2012. It has implemented the $1998 \mathrm{UN}$ Guiding principles on internal displacement (UN doc. $\mathrm{E} / \mathrm{CN} .4 / 1998 / 53 /$ Add.2).

3 Among recent instruments, one has to mention the 2018 Global Compact for Safe, Orderly and Regular Migration, listing a set of commitments to limit the adverse drivers and structural factors (including climate change) that compel people to leave their country of origin (see UN doc. A/CONF.231/3, Annex, Objective 2). For a general survey on the state of the art of the legal framework at European level, see Hélène Ragheboom, The international legal status and protection of environmentally-displaced persons: A European perspective (Brill Nijhoff 2017).

4 Cf. doc. $\mathrm{N} 2307$ (2019). The text of the Resolution is available at $<\mathrm{http}$ ://assembly.coe.int/nw/ $\mathrm{xml} / \mathrm{XRef} /$ Xref-XML2HTML-EN.asp?fileid=28239\&lang=en >. 
mechanisms. The main assumption upon which that approach is based is that human migration should be recognised by the Member States as a tool for increasing 'livelihood resilience' and as a legitimate form of adaptation to climate change. States should thus revise their national strategies and migration management mechanisms to include that paradigm shift. On the one hand, this should lead to an increase in local communities' thresholds for resilience, in accordance with the Goal 11 of the United Nations Sustainable Development Goals as well as the Sendai Framework for Disaster Risk Reduction 2015-2030. ${ }^{5}$ On the other, the human-right dimension of the environmentally induced migration should be taken into consideration with a view to strengthening the protection of interested people.

From this perspective, the Resolution firstly recognises that the obligation to protect internally displaced persons lies under the responsibility of Member States and should represent the first level of legal protection in their legislation. ${ }^{6}$ Once recognised the primary role of the affected State, the Resolution considers actions that Member States should put in place to manage 'climate migration'. In this respect, reference is made to the promotion of European development cooperation programmes, funded by the Member States, to support the proper implementation of mechanisms protecting human mobility following environment-related disasters of climate change (such as the Kampala Convention). But the Resolution goes further than this: it urges Member States to pass municipal law reforms recognising the temporary residence status to natural disasters victims having a different nationality. ${ }^{7}$ Even more importantly, due to the protection gap of the 1951 Convention relating to the status of refugees, ${ }^{8}$ the Resolution calls for specific actions to be taken by Member States to develop in their asylum systems - and at international level - protection for people fleeing from long-term climate change in their native countries. According to the PACE Resolution, indeed, ' $t$ ] he industrialised Member States of the Council of Europe carry a particular responsibility to those countries, especially the countries of the 'global South' affected by man-made

5 Paras. $5.1-5.2$ of the Resolution.

6 Ibid., para. 5.3.2. This statement echoes the content of the Draft article 10, para. 2, of the 2016 ILC Draft articles on the protection of persons in the event of disasters, stating that ' $[\mathrm{t}] \mathrm{he}$ affected State has the duty to ensure the protection of persons and provision of disaster relief assistance in its territory, or in territory under its jurisdiction or control'.

7 Para. 5.3.2 of the Resolution.

8 As it is well-known, the capacity of the $195^{1}$ Refugee Convention to respond to the needs of persons outside the classic refugee paradigm (including 'climate refugees') is still disputed. See on that Matthew Scott, Climate change, disasters, and the Refugee Convention (cup 2020). 
climate change, and should, therefore, provide appropriate asylum for climate refugees.9 In this light, the Resolution represents a relevant step in the elaboration of a European approach to address the protection shortcomings showed by the existing international refugee law with regard to "climate refugees."10

In 2019, the Organisation for Economic Co-operation and Development (OECD) adopted two reports dealing with disaster scenarios. The first report, 'Fiscal Resilience to Natural Disasters. Lessons from Country Experiences', has been prepared in cooperation with the World Bank and takes stock of how governments in OECD and non-OECD countries manage the implications of natural disasters for public finances. ${ }^{11}$ The report reveals a variety of solutions adopted by States to provide financial assistance in the event of a disaster. In particular, while some countries have clearly identified the role that central government may play in providing assistance, many others have established a general commitment of giving assistance, without identifying related actors and procedures. Similar ambiguities are also present when it comes to the sharing of costs between central governments and subnational authorities. This is why the drafters of the report recommend the adoption of a clear legal framework for government's post-disaster financial assistance, which should also shed light on cost-sharing across the different levels of government. Among the other recommendations, the report includes: the need to incorporate an assessment of disaster-related contingent liabilities in fiscal risk management framework; the possibility to consider the elaboration of DRR strategies by relevant actors as a pre-requisite for having access to higher damages reimbursement rates; and the elaboration of multi-pronged financial protection strategies to manage fiscal risk.

The second report, 'Good Governance for Critical Infrastructure Resilience,'12 was prepared by the OECD Public Governance Directorate to assess OECD

$9 \quad$ Para. 5.4 of the Resolution.

10 On a possible European approach thereto, see also Joanna App, The concept of "climate refugee". Towards a possible definition, European Parliament Briefing, February 2019, available at <https://www.europarl.europa.eu/RegData/etudes/BRIE/ 2018/621893/EPRS_BRI(2018)621893_EN.pdf>.

11 Text available at <http://www.oecd.org/governance/fiscal-resilience-to-natural-disasters $-27 \mathrm{a} 4198 \mathrm{a}-\mathrm{en} \cdot \mathrm{htm}>$.

12 Text available at <http://www.oecd.org/gov/risk/good-governance-for-critical-infrastruc ture-resilience-o2foe5ao-en.htm>. 
countries' public policies to support the protection of critical infrastructure. Even though the majority of those countries have elaborated relevant strategies, in particular within the respective post-9/11 security agendas, several shortcomings may be identified in terms of lack of effectiveness. In the light of that, the report suggests the adoption of a coherent, system-based approach, covering all hazards and threats while ensuring strict co-ordination across multiples sectors and different (public and private) actors involved in that domain. The Report also proposes a Policy Toolkit on Governance of Critical Infrastructure Resilience, which is based on the following 7 challenges: 1) creating a multi-sector governance structure for critical infrastructure resilience; 2) assessing interdependencies and vulnerabilities across infrastructure systems; 3) creating a mutual trust between governments and actors through an exchange of information on risk and vulnerabilities; 4) establishing partnerships between governments and critical infrastructure operators on resilience objectives; 5) identifying the policy tools to encourage operators to invest in resilience and achieve resilience objectives; 6) ensuring accountability and monitoring implementation of critical infrastructure resilience policies, and 7) facing the cross-border dimension of infrastructure systems.

At the EU level, the most relevant developments occurred in 2019 within the domain of disaster law concern 1) the reform of the Union Civil Protection Mechanism and the implementation of its new toolkit; and 2) the adoption of a new general strategy to face the climate change and other environmental challenges.

\subsection{The Reform of the Union Civil Protection Mechanism}

As we mentioned in the previous issue of this Yearbook, at the end of 2018 an agreement was reached between the European Parliament and the Council of the European Union to revise the decision establishing the Union Civil Protection Mechanism (UCPM) ${ }^{13}$ In 2019 the EU Parliament and the Council adopted the text of the new decision reshaping the Mechanism. ${ }^{14}$

13 Federico Casolari, 'Europe (2018)', (2019) 1 Yearbook of International Disaster Law, 346. The UCPM was established by Decision No 1313/2013 of the European Parliament and of the Council, oJ L347, 20 December 2013, 924.

14 Cf. Decision (EU) 2019/420 of the European Parliament and of the Council of 13 March 2019 amending Decision No 1313/2013/EU on a Union Civil Protection Mechanism, OJ L771, 20 March 2019, 1. 
Its rationale lies in the strengthening of cooperation among Member States ${ }^{15}$ while reinforcing the EU's ability to respond to disasters (inside and outside the Union). In this respect, the two major pillars of the reform are represented by the reshaping of the European Civil Protection Pool and the introduction of rescEU.

The management of voluntarily pre-committed response capacities of the MemberStates composing the Pool has been significantly amended by providing increased Union financing to the Member States for the adaptation, repair and operating costs of Pool capacities or States' capacities that are in turn included in European Civil Protection Pool and used to respond to future disasters. ${ }^{16}$ Moreover, a Civil Protection Knowledge Network has been established, ${ }^{17}$ with a view to bringing together a full range of expertise on disasters (e.g. civil protection and disaster management actors, institutions, centres of excellence, universities, researchers and the European Commission). The Network shall develop activities in the field of training, exercises, lessons learnt and knowledge dissemination, facilitating the exchange of best practices and contributing thus to the creation of a "common language" on disaster management at the supranational level.

RescEU capacities are introduced in the EU civil protection toolkit to provide assistance in overwhelming situations where overall existing capacities at the national level and those pre-committed by Member States of the European Civil Protection Pool are not able to ensure an effective response to the disaster. ${ }^{18}$ Those capacities shall be acquired, rented or leased by the Member States with the financial support of the European Commission. Moreover, the Commission may procure capacities on behalf of the Member States. Quality requirements of rescEU capacities are defined by the European Commission, in consultation with the Member States. While the decision on the deployment and demobilisation of rescEU capacities is taken by the Commission in close coordination with the requesting Member State and the Member State owing, renting or leasing the capacity, it is for the Member State on the territory of which rescEU capacities are deployed to direct response operations. In the case of deployment outside the Union, the Member States hosting the capacities are responsible for making sure that rescEU capacities are integrated into the overall response.

15 In the light of article 28(1)a of Decision No 1313/2013/EU, where reference is made here to Member States, it shall be understood as including all Participating States as defined in article 4(12) of the same Decision (i.e. third countries participating in the Mechanism).

16 Article 21 of the amended Decision No $1313 / 2013$.

17 Ibid., article 13.

18 Ibid., article 12. 
Last but not least, the amendments introduced in 2019 have strengthened the disaster-prevention actions to be developed within the Mechanism, further supporting the Member States in improving their risk management. ${ }^{19}$ In particular, it is requested that the Member States provide the Commission with relevant aspects of their risk assessments and the assessment of their risk management capability focusing on key risks. They are also requested to provide information on the priority measures needed to address key risks with cross-border implications and low probability risks with a high impact. ${ }^{20}$

The revised legal framework of the cooperation between the Union and the Member States in civil protection domain has been further defined in the next months of 2019 by means of implementing decisions adopted by the European Commission. In April, a decision laying down rules on rescEU capacities has been adopted. ${ }^{21}$ It has defined the initial composition of rescEU, introducing aerial forest firefighting capacities (aeroplanes and helicopters) to respond to wildfires, and fixing related quality requirements. That decision has been then amended to include capacities relating to the emergency medical response. ${ }^{22}$ In July, the European Commission has adopted another decision laying down rules for the establishment, management and maintenance of rescEU capacities. ${ }^{23}$ Due to space constraints, it not possible to analyse in-depth the decision's contents. It suffices to mention here some basic provisions related to the criteria for deployment decisions on rescEU capacities and for demobilisation and disengagement decisions, the national use of those capacities, and the refusal to deploy personnel outside the Union, respectively.

Pursuant to article 3 of the implementing decision, rescEU capacities shall be deployed taking into account the following criteria: (a) the operational situation across Member States as well as potential disaster risks; (b) the appropriateness and adequateness of rescEU capacities to respond to the disaster at stake; (c) the geographic location of relevant capacities; (d) the terms and conditions contained in the operational contracts related to

19 Ibid., article 6.

20 The European Commission has adopted a set of guidelines to support Member States in fulfilling such reporting duties: Reporting Guidelines on Disaster Risk Management, oJ $\mathrm{C}_{428}$, 20 December 2019, 8.

21 Implementing Decision (EU) 2019/570 of 8 April 2019, OJ L99, 10 April 2019, 41.

22 In particular, rescEU capacities for medical aerial evacuation of disasters victims and an emergency medical team. Cf. Implementing Decision (EU) 2019/1930 of 18 November 2019, OJ L299, 20 November 2019, 55 .

23 Implementing Decision (EU) 2019/1310 of 31 July 2019, OJ L2014, 2 August 2019, 94. The piece of legislation also fixes the minimum periods of commitment of capacities under the European Civil Protection Pool (article 2). 
rescEU capacities. ${ }^{24}$ The same criteria shall be taken into consideration when a decision to disengage shall be adopted by the Commission. Such a decision is needed when there is a greater operational need for the capacity elsewhere or the situation on the field no longer justify its use. Article 5 regulates the national use of rescEU capacities, which is subject to strict limitations. Indeed, Member States shall ensure that the needed capacities under the Union Mechanism are made available with the shortest period. This said States using rescEU capacities for national purposes shall ensure equal treatment of the former with national capacities with regard to maintenance, storage, insurance, staffing and other relevant activities. Moreover, they shall ensure a rapid repair in case of damage. Finally, article 6 makes it clear that, in case of deployment of rescEU capacities outside the Union, Member States may refuse to deploy their personnel where (a) diplomatic relations with the requesting States have been severed or (b) an armed conflict, the threat thereof, or other serious ground may represent a serious risk for the safety and security of personnel.

\subsection{A Green New Deal for the Union?}

In December 2019 the European Commission adopted 'The European Green Deal', a new growth strategy aiming at making the EU a fair and prosperous society without emission of greenhouse gases in 2050 and where the economic development is decoupled from resource use. ${ }^{25}$

Such an ambitious strategy requires a general reshaping of EU policies, making sustainability an imperative of all EU actions. In particular, in the Commission's view, the transformation of EU economy should be based on 8 main drivers: 1) the increase of EU climate ambition for 2030 and $2050 ; 26$ ) an EU energy supply clean, affordable and secure; 3 ) the involvement of industry for transformative actions towards a clean and circular economy; ${ }^{27} 4$ ) building and renovating in an energy and resource efficient way; 5) accelerating the

24 Additional criteria are identified in the case of conflicting requests for assistance. Inter alia, the Commission shall consider the projected risks to human lives and critical infrastructures, the potential impact of the disaster and the risk of disaster spreading.

25 Doc. Сом (2019) 640 final, 11 December 2019.

26 In 2019 the EU legislature has adopted normative instruments with the aim of climate neutrality: cf. Regulation (EU) 2019/631 of 17 April 2019 setting $\mathrm{CO}_{2}$ emission performance standards for new passenger cars and for new light commercial vehicles (OJ L111, 25 April 2019, 13) and Regulation (EU) 2019/1242 of 20 June 2019 setting $\mathrm{CO}_{2}$ emission performance standards for new heavy-duty vehicles (OJ L198, 25 July 2019, 202).

27 In this respect, it is noteworthy that in 2019 a directive on the reduction of the impact of certain plastic products on the environment has been adopted (Directive (EU) 2019/904 of 5 June 2019, OJ L155, 12 June 2019, 1). 
shift to sustainable and smart mobility; 6) the elaboration of a new approach to food sustainability; 7) preserving and restoring ecosystems and biodiversity; 8) creating a toxic-free environment.

Particular emphasis is then put on the role the Union should play on the international scene. In this light, the strategy urges first the Union to keep its efforts in relevant international fora to ensure that the Paris Agreement remains the cornerstone of the multilateral framework for tackling climate change. At the same time, the trade policy is understood as a preferential means to develop bilateral or multilateral cooperating platforms on climate and environmental action. Quite interestingly, the strategy provides that the Commission will propose to make the respect of the Paris Agreement an essential element for all future trade agreements of second generation entered into by the Union. ${ }^{28}$ On the one hand, this means that the Union could decide to make the conclusion of new agreements conditional on the other contracting parties' ratification and implementation of the Paris Agreement. On the other, the fact that the respect of the commitments flowing from the Paris Agreement is understood as an 'essential element' of the trade contractual relations of the Union could lead the latter - in the event of a serious violation of related obligations by the co-contracting parties - to invoke the "material breach" clause enshrined in article 6o of the 1969 Vienna Convention of the Law of Treaties ('VCLT'), leading thus to the termination or suspension (in whole or in part) of the agreement at stake. ${ }^{29}$ Lastly, the strategy emphasises the leading role the EU may assume in setting standards applicable across global value chains.

28 It is important to stress that the proper implementation of the Paris Agreement is already mentioned in some agreements concluded by the Union. The reference to the Paris Agreement is usually contained in the Trade and Sustainable Development ('TSD') chapters of those agreements. Cf. article 16.4(4) of the Economic Partnership Agreement with Japan, article 12.6(3) of the Free Trade Agreement with Singapore, article 6(2)a of the EU-Mercosur Trade Agreement, and article 5(2)a of the EU-Mexico Agreement (the texts of the agreements are available at <https:/ec.europa.eu/trade/policy/countries -and-regions/negotiations-and-agreements/>). This said, the effectiveness of those provisions is still debatable: their language is rather aspirational and, most importantly, the dispute-resolution mechanism of TSD chapters is quite soft for it is based on consultation and dialogue. See also The Economist - Intelligence Unit, Climate change and trade agreements. Friends or foes?, 2019, available at <https://iccwbo.org/content/uploads/ sites/3/2019/o3/icc-report-trade-and-climate-change.pdf $>$.

29 Cf. also the answer given by the former Commissioner for Trade, Ms Cecilia Malmström, to a question posed by MEP Karoline Graswander-Hainz (doc. P-oo4848-17, available at <https://www.europarl.europa.eu/doceo/document/P-8-2017-004848-ASW_EN.html>), stressing the possibility to invoke the VCLT in similar cases. Needless to say, the Vienna Convention is applicable to the Union to the extent that its content reflects customary international law (the EU is not a party to that Convention). 